\title{
ANNA DOBACZEWSKA
}

ORCID: 0000-0001-8918-9847

Uniwersytet Gdański

anna.dobaczewska@prawo.ug.edu.pl

\section{Zasady prawne relacji przedsiębiorców z organami władzy publicznej}

\begin{abstract}
Abstrakt: Niniejsze opracowania jest próbą oceny, czy i w jakim zakresie zmiany legislacyjne z lat 2015-2019 przyniosły realne zmiany dla prowadzących działalność gospodarczą, w szczególności w ich relacjach z organami administracji publicznej, w tym w postawie oczekiwanej od organów wobec przedsiębiorców. Nie mniej istotne jest zwrócenie uwagi na zasady, jakimi powinien kierować się ustawodawca, uchwalając prawo regulujące warunki podejmowania i wykonywania działalności gospodarczej. Artykuł koncentruje się na ewentualnych różnicach między zasadami zawartymi w Konstytucji RP oraz kodeksie postępowania administracyjnego a katalogiem podstawowych zasad prowadzenia działalności gospodarczej i zasad stanowienia prawa gospodarczego zawartych w ustawie Prawo przedsiębiorców.
\end{abstract}

Słowa kluczowe: zasady, mali przedsiębiorcy, mikroprzedsiębiorcy, konstytucja dla biznesu.

Bezsprzecznie do fundamentalnych zasad prawa gospodarczego publicznego zalicza się zasada wolności gospodarczej. Rozumiana jest ona współcześnie nie tylko jako niestawianie przedsiębiorcom różnorakich barier przez organy władzy publicznej, lecz także jako stwarzanie takiego otoczenia prawnego i instytucjonalnego, które ułatwiłoby podjęcie decyzji o rozpoczęciu lub ekspansji własnej działalności gospodarczej przez podmioty prywatne. Będąc zasadą konstytucyjną, zasada wolności gospodarczej znalazła swoje rozwinięcie w ustawach odnoszących się do przedsiębiorców, a w szczególności w ustawie z 6 marca 2018 roku Prawo przedsiębiorców (i pozostałych ustawach należących do pakietu nazwanego konstytucją dla biznesu). Wyznaczają one między innymi granice wpływu państwa na zjawiska gospodarcze ${ }^{1}$, a tym samym na status przedsiębiorcy.

Jednym z celów zmian legislacyjnych było stworzenie podstaw prawnych rozwoju przedsiębiorczości przez nowe uregulowanie uprawnień przedsiębior-

1 K. Strzyczkowski, Prawo gospodarcze publiczne, Warszawa 2011, s. $80 \mathrm{n}$.

Prawo 329, 2020

(C) for this edition by CNS 
ców w ich kontaktach z organami administracji publicznej. Niniejsze opracowanie jest próbą oceny, czy i jakie potencjalnie nowe elementy ułatwiające przedsiębiorcom decyzję o rozpoczęciu działalności gospodarczej oraz jakie ułatwienia, by zminimalizować obciążenia formalne związane z prowadzeniem działalności gospodarczej zostały wprowadzone przez ustawodawcę w kadencji Sejmu 2015-2019. Punktem wyjścia tych rozważań jest między innymi dokument programowy rządu Plan na rzecz odpowiedzialnego rozwoju ${ }^{2}$. Według intencji jego twórców zmiany w przestrzeni prawnej i instytucjonalnej stanowiące ułatwienia w podjęciu ryzyka gospodarczego realizują się za sprawą zmniejszenia barier formalnych, fiskalnych i prawnych nałożonych na przedsiębiorców. Tekst ten odnosi się do tych najbardziej znaczących rozwiązań prawnych ${ }^{3} \mathrm{i}$ instytucjonalnych ${ }^{4}$, ze szczególnym uwzględnieniem zmian na rzecz sektora mikro-, małych i średnich przedsiębiorców.

$\mathrm{Na}$ wstępie pojawia się pytanie, czy i w jakim stopniu zmiany te prowadzą do rzeczywistego, a nie jedynie deklarowanego wzrostu wsparcia dla przedsiębiorców i w jakim stopniu są to instrumenty nowe, nieznane wcześniej polskiemu ustawodawstwu. Celem artykułu jest analiza zmian legislacyjnych pod kątem wykazania, czy nastąpiła zmiana jakościowa w zakresie wsparcia decyzji przedsiębiorców o podejmowaniu i prowadzeniu działalności gospodarczej. Prowadzi ona do wniosku, że zmiany legislacyjne koncentrują się wokół likwidowania barier administracyjnych dla przedsiębiorców o mniejszej skali oraz formalnej reorganizacji istniejących instytucji wsparcia. Mniej znaczące są zmiany w odniesieniu do poszerzenia dostępu do kapitału dla przedsiębiorców podejmujących się innowacji. Okazuje się, że realnych zmian, wyraźnie ułatwiających działanie przedsiębiorcom, jest stosunkowo niewiele. Zmiany koncentrują się w dodatku wokół nowelizacji przepisów dotychczasowych. Także sam proces ustawodawczy odnośnie do wspomnianych zmian przebiegał nierzadko w taki sposób, że przedsiębiorcy byli zaskakiwani zmianami przepisów, a organy administracji nie były w stanie się do nich na czas przygotować. Nawet zakładając, że były to zmiany dla

2 https://www.gov.pl/web/inwestycje-rozwoj/plan-na-rzecz-odpowiedzialnego-rozwoju (dostęp: 30.09.2019).

3 Odnoszę się w opracowaniu do tych zmian, które rzutują na wzajemne relacje między przedsiębiorcami a organami publicznymi. Dlatego też tak istotne kwestie jak prawne uregulowanie sukcesji generalnej mającej za przedmiot przedsiębiorstwo w spadku (oraz związanych z nim koncesji, licencji czy zezwoleń) ani tak zwana prosta spółka akcyjna, możliwa do powołania od 1 marca 2020 roku, nie zostaną omówione.

${ }^{4}$ Ograniczenia redakcyjne nie pozwalają pochylić się nad rozwiązaniami wspierającymi o charakterze finansowym, zwłaszcza w zakresie obciążeń fiskalnych, jak tak zwany mały ZUS, dobrowolne składki na ubezpieczenie społeczne (ale nie zdrowotne) dla początkujących przedsiębiorców, tak zwane wsparcie na starcie w postaci niskooprocentowanych pożyczek BGK, działalność PARP czy PAIH w zakresie promocji eksportu itp. (jako instytucji rozwoju) czy całej tak zwanej grupy PFR. Wzmiankowana zostanie jedynie rola Rzecznika Małych i Średnich Przedsiębiorców jako swoistego mediatora między organami władzy publicznej a przedsiębiorcami.

Prawo 329, 2020

(C) for this edition by CNS 
przedsiębiorców pozytywne, to nazbyt pochopne działania nigdy nie są korzystne z perspektywy zaufania obywateli do państwa i jego organów.

W literaturze ${ }^{5}$ dowodzi się, że do głównych barier należą nadmierne formalności administracyjne, koszty pracy, wysokość obciążeń podatkowych i innych należności publicznych, a także tak zwana luka kapitałowa, czyli brak dostępu do kapitału niezbędnego do rozwoju przedsiębiorców (dotyczy to zwłaszcza małych i początkujących przedsiębiorców, w tym innowacyjnych). Niezależnie, jaka miałaby być hierarchia ważności tych powodów, rolą państwa dążącego do wzrostu gospodarczego jest zachęcać i wspierać obywateli w ich decyzji podjęcia ryzyka gospodarczego przez pozytywne działania. Tymczasem na próżno w obowiązującym prawodawstwie szukać następcy art. 103 ustawy o swobodzie działalności gospodarczej ${ }^{6}$, stanowiącego wyraźnie, iż „państwo stwarza [...] korzystne warunki dla funkcjonowania i rozwoju mikroprzedsiębiorców, małych i średnich przedsiębiorców”. Taka konstatacja poparta była egzemplifikacją:

- działań w zakresie ustawodawstwa (inicjowanie zmian legislacyjnych i dbanie o to, aby obowiązki MŚP wobec organów administracji nie były nadmierne);

— wspierania instytucji i organizacji działających na rzecz przedsiębiorców;

- inicjowania zmian prawnych w zakresie dostępu mikro-, małych i średnich przedsiębiorców do kapitału;

— wspierania w ramach realizacji programów rządowych instytucji, które takiego finansowania udzielają.

Ułatwienia odnoszące się do likwidacji barier prawnych czy finansowych, o których wspominają dokumenty i programy rządowe z lat 2015-2019 nie są zatem nowatorskie w swym zamyśle. Jednocześnie jednak niesformułowanie wyraźnego zobowiązania do wspierania przedsiębiorców nie oznacza, jakoby rząd nie podejmował inicjatyw służących takiemu wsparciu.

Warto przy tym podkreślić, że ani wspomniane bolączki przedsiębiorców, ani próby zaradzenia im nie są specyfiką wyłącznie polską. Zwłaszcza idea wspierania przede wszystkim grupy przedsiębiorców mikro-, małych i średnich jest w istocie realizacją postulatów zawartych w dokumentach UE. Chodzi przede wszystkim o takie programy ramowe Komisji Europejskiej, jak Think Small First, a Small business Act for Europe ${ }^{7}$ oraz Plan działania na rzecz przedsiębiorczości do 2020

5 A. Samborski, Bariery fiskalne rozwoju przedsiębiorczości w Polsce, „Problemy Zarządzania” 2017, nr 1 (65), s. 56; E. Grzegorzewska-Mischka, W. Wyrzykowski, Bariery rozwoju przedsiębiorczości w Polsce i krajach UE - analiza retrospektywna i porównawcza, [w:] Przedsiębiorczość w dobie wyzwań rozwojowych, red. Ł. Sułkowski, A. Marjański, „Przedsiębiorczość i Zarządzanie” 18, 2017, nr 12, cz. 1, s. 183, 186.

${ }^{6}$ Ustawa z dnia 2 lipca 2004 roku o swobodzie działalności gospodarczej (tekst jedn. Dz.U. z 2017 r. poz. 2168 ze zm.).

7 Komunikat Komisji do Rady, Parlamentu Europejskiego, Europejskiego Komitetu Ekonomiczno-Społecznego i Komitetu Regionów, Think Small First, a Small Business Act for Europe, 
roku ${ }^{8}$. Wskazują one na inicjatywy konieczne, zarówno po stronie prawodawcy unijnego, jak i władz państw członkowskich, do zwiększenia przedsiębiorczości i przyczynienia się do wzrostu gospodarczego.

Zmiany prawa dokonane podczas ostatniej kadencji Sejmu podejmowane były etapowo i najczęściej przybierały postać ustaw zbiorczo nowelizujących najbardziej naglące zagadnienia lub te $\mathrm{z}$ nich, które stosunkowo łatwo i szybko można było wprowadzić. Pierwsza z nich to ustawa z 16 grudnia 2016 roku$^{9}$, zasadniczo obowiązująca od 1 stycznia 2017 roku, a rozpowszechniana jako program 100 zmian dla firm. De facto ten element zmian obejmował kilka etapów (od stycznia 2017 do 1 stycznia 2019 roku), sukcesywnie wprowadzających raczej drobiazgowe zmiany niż rozwiązania systemowe. Wśród nich można wydzielić zmiany instytucjonalne, prawne - w znaczeniu wykreowania nowych rozwiązań $\mathrm{i}$ form prawnych dla prowadzenia działalności gospodarczej - i w (niewielkim stopniu) finansowe formy wsparcia. Do najbardziej znaczących można zaliczyć regulacje o sukcesji przedsiębiorstwa osoby fizycznej ${ }^{10}$, o tak zwanej prostej spółce akcyjnej czy też prawo do powoływania prokurentów przez przedsiębiorców zarejestrowanych w CEIDG. Są to rozwiązania wcześniej nieistniejące, mające walor udogodnienia dla przedsiębiorców i stanowiące przykłady twórczych rozwiązań ułatwiających prowadzenie działalności gospodarczej.

Najważniejsze zmiany zdawała się przynosić pod koniec kwietnia 2018 roku tak zwana konstytucja dla biznesu, będąca w praktyce pakietem pięciu ustaw: Prawo przedsiębiorców ${ }^{11}$, ustawy o CEIDG, ustawy o zasadach uczestnictwa przedsiębiorców zagranicznych i innych osób zagranicznych w obrocie gospodarczym na terytorium Rzeczypospolitej Polskiej, ustawy o Rzeczniku Małych i Średnich Przedsiębiorców oraz przepisów wprowadzających.

https://eur-lex.europa.eu/legal-content/EN/TXT/?uri=CELEX:52008DC0394 (dostęp: 30.09.2019); A. Samborski, op. cit., s. 51.

${ }^{8}$ Komunikat Komisji do Parlamentu Europejskiego, Rady, Europejskiego Komitetu Ekonomiczno-Społecznego i Komitetu Regionów, Plan działania na rzecz przedsiębiorczości do $2020 \mathrm{r}$. Pobudzanie ducha przedsiębiorczości w Europie, Bruksela 9 stycznia 2013 roku, COM (2012) 795 final, s. 17.

9 Ustawa z dnia 16 grudnia 2016 roku o zmianie niektórych ustaw w celu poprawy otoczenia prawnego przedsiębiorców (Dz.U. z 2016 r. poz. 2255 ze zm.).

10 Ustawa z dnia 5 lipca 2018 roku o zarządzie sukcesyjnym przedsiębiorstwem osoby fizycznej (Dz.U. z 2018 r. poz. 1629 ze zm).

11 Ustawa z dnia 6 marca 2018 roku Prawo przedsiębiorców (tekst jedn. Dz.U. z 2019 r. poz. 1292 ze zm.); ustawa z dnia 6 marca 2018 roku o Centralnej Ewidencji i Informacji o Działalności Gospodarczej i Punkcie Informacji dla Przedsiębiorcy (tekst jedn. Dz.U. z 2019 r. poz. 1291 ze zm.); ustawa z dnia 6 marca 2018 roku o Rzeczniku Małych i Średnich Przedsiębiorców (Dz.U. poz. 648); ustawa z dnia 6 marca 2018 roku o zasadach uczestnictwa przedsiębiorców zagranicznych i innych osób zagranicznych w obrocie gospodarczym na terytorium Rzeczypospolitej Polskiej (tekst jedn. Dz.U. z 2019 r, poz. 1079 ze zm.); ustawa z dnia 6 marca 2018 roku Przepisy wprowadzające ustawę Prawo przedsiębiorców oraz inne ustawy dotyczące działalności gospodarczej (Dz.U. z 2018 r. poz. $650)$. 
Prawo przedsiębiorców nie odznacza się doniosłością w przedmiocie zmian prawnych, choć w ustawie tej akcentowane jest nowe znaczenie relacji między organami administracji publicznej a przedsiębiorcami. Zastanawia przede wszystkim poświęcenie tak dużo miejsca zasadom kontroli przedsiębiorców, skoro same gwarancje swobody gospodarczej i ochrony przed nadmierną kontrolą bynajmniej nie uległy poprawie. Liczba wyjątków, kiedy instrumenty ochronne przedsiębiorców nie mają zastosowania (takie jak zasada jednej kontroli w tym samym czasie, limit liczby kontroli oraz limit dni trwania kontroli w danym roku), pozostała bez zmian; większa zaś szczegółowość postanowień dotyczących kontroli nie wydaje się przekładać na większe zaufanie przedsiębiorców do organów administracji. Przeciwnie - rozbudowana regulacja kontroli, wzajemnych praw i obowiązków zdaje się odnosić skutek odwrotny do zamierzonego. Również katalog zasad mających chronić przedsiębiorców przed nadużyciami ze strony organów administracji jest zasadniczo bardzo podobny do tego, który znajdujemy w rozdziale 2 kodeksu postępowania administracyjnego ${ }^{12}$, zawierającego podstawowe zasady postępowania administracyjnego.

Konstytucja dla biznesu była przedstawiana jako największa od lat zmiana jakościowa relacji przedsiębiorców z organami władzy publicznej, tym czasem rozczarowuje pod względem liczby rozwiązań, które nie byłyby wcześniej znane polskiemu prawu (na przykład administracyjnemu). Dotyczy to także zasad odnoszących się do relacji przedsiębiorcy z organami administracji publicznej. Uwagę przykuwają w tej kwestii zasady postępowania organów administracji wobec przedsiębiorców.

Przepisy ustawy Prawo przedsiębiorców wprawdzie odnoszą się do wszelkich relacji organów administracji z przedsiębiorcami, nawiązują bowiem do „załatwiania spraw", czyli nie zawężają się do stosunków z przedsiębiorcami będącymi (już) stroną postępowania administracyjnego, jak czyni to k.p.a., ale innych sytuacji w praktyce nie będzie wiele. Ponadto ten sam efekt ochrony można było osiągnąć, zmieniając zakres zastosowania zasad z k.p.a. również na pozostałe relacje organów administracji z adresatami ich czynności (rozszerzyć ich zastosowanie poza postępowanie administracyjne sensu stricto). W obecnym kształcie katalog zasad załatwiania spraw z zakresu działalności gospodarczej stanowi w dużej części superfluum (zasada szybkości postępowania, rozsądnych terminów, udzielania stronie informacji czy pogłębiania zaufania do organów, a także zasada pewności prawa są znane procedurze administracyjnej).

Podobnie zbędne jest wskazanie, że przedsiębiorca może korzystać z zasady „co nie jest zakazane, jest dozwolone”. Powtarza ona i tak już obowiązującą zasadę wolności gospodarczej i zasadę swobody umów. Jak stanowi Konstytucja RP (art. 22), swobodę gospodarczą można ograniczyć tylko w drodze ustawy, a zatem

12 Ustawa z dnia 14 czerwca 1960 roku - Kodeks postępowania administracyjnego (tekst jedn. Dz.U. z 2018 r. poz. 2096 ze zm.). 
wszelkie zakazy powinny być wyraźnie zawarte w przepisach, a nie dorozumiane przez urzędników.

Również stwierdzenie, że wątpliwości co do okoliczności faktycznych powinny być rozstrzygane na korzyść przedsiębiorcy nie jest całkowicie obce polskiemu prawu. Zasada ta (w okrojonej formie) znana jest już na przykład prawu podatkowemu jako zasada in dubio pro tributario. Ponadto gospodarzem postępowania administracyjnego i podmiotem odpowiedzialnym za zgromadzenie pełnego i wiarygodnego materiału dowodowego jest organ administracyjny i tylko na jego podstawie mogą być wydawane rozstrzygnięcia organów administracyjnych. Zadaniem organów jest zatem wyeliminowanie niejasności, a w wypadku niemożności wyeliminowania ich rozstrzygnięcie na korzyść strony.

Tego rodzaju przepisy mogły pojawić się w regulacjach dotyczących przedsiębiorców już równolegle do nowelizacji k.p.a. z kwietnia 2017 roku, która odnosiła się między innymi do zasad postępowania administracyjnego. Prawo przedsiębiorców zastrzega przy tym, że taka przyjazna przedsiębiorcy interpretacja przepisów nie ma zastosowania, jeśli sprzeciwiają się temu istotne interesy państwa (art. 11 ust. 2 ustawy prawo przedsiębiorców). Zasada ta może zatem podlegać daleko idącym ograniczeniom z uwagi na wykorzystanie przez ustawodawcę klauzuli generalnej. Nowością w stosunku do treści k.p.a. są natomiast zasada domniemania uczciwości przedsiębiorcy i domniemanie poszanowania przez niego dobrych obyczajów.

Po lekturze wspomnianych przepisów nasuwa się wniosek, że przedsiębiorcy nie są bynajmniej objęci znacznie mocniejszą ochroną, niż byli w okresie obowiązywania poprzedniej ustawy, ani nie mają bardziej uprzywilejowanej pozycji względem innych stron postępowań administracyjnych, które przedsiębiorcami nie są, a których prawa i obowiązki zostały ujęte w k.p.a. Ponadto brakuje w przepisach (nie tylko) ustawy Prawo przedsiębiorców zarówno jakichkolwiek mechanizmów kontroli przestrzegania tychże zasad, jak i możliwości wyegzekwowania ich po stronie przedsiębiorców, co sprawia, że zmiana nastawienia urzędników wobec przedsiębiorców może okazać się iluzoryczna.

Jako kolejny przykład zmian legislacyjnych mających być ułatwieniem dla osób fizycznych prowadzących działalność zarobkową jest wprowadzenie do ustawy Prawo przedsiębiorców tak zwanej działalności nierejestrowanej. Tylko prima facie może to być wsparciem i ułatwieniem dla poczatkujących przedsiębiorców lub prowadzących ją niejako ubocznie. Osoby fizyczne osiągające przychody niższe niż 50\% minimalnego wynagrodzenia są zwolnione z obowiązku rejestracji w CEIDG. Nie są jednak zwolnione ani z rejestracji i pozyskania NIP, ani z obowiązku prowadzenia ewidencji sprzedaży, ani używania kasy fiskalnej (tam gdzie ma to zastosowanie), ani odprowadzania podatku dochodowego według zasad ogólnych, ani z naliczania VAT. Również na gruncie kodeksu cywilnego taki podmiot nie przestaje być przedsiębiorcą, co powoduje, że nadal jest zobowiązany do zachowania zawartych w nim przepisów chroniących konsumentów. 
Najważniejszym osiągnięciem konstytucji dla biznesu okazało się utworzenie nowej instytucji, jaką jest Rzecznik Małych i Średnich Przedsiębiorców (dalej: Rzecznik) $)^{13}$. Na marginesie warto zaznaczyć, że obejmuje on swą właściwością oczywiście także ochronę praw mikroprzedsiębiorców, w szczególności osób fizycznych (stanowiącą ich zdecydowaną większość). Mimo ujętych w ustawie Prawo przedsiębiorców już wskazanych gwarancji wolności gospodarczej oraz istnienia innych rzeczników, takich jak Rzecznik Finansowy, Rzecznik Praw Obywatelskich, to znaczenie wsparcia udzielanego przedsiębiorcom przez nowego Rzecznika może być istotne. Wprawdzie formalnie wszystkie organy administracji mają zakładać uczciwość przedsiębiorców, interpretować przepisy i ustalony stan faktyczny na ich korzyść, ale dotychczasowa praktyka dowodzi, iż zwłaszcza mikro- i mali przedsiębiorcy nie są $\mathrm{w}$ stanie samodzielnie zadbać o własne interesy. Dlatego Rzecznik prowadzi działalność interwencyjną przede wszystkim w zakresie ich relacji z organami administracji, zarówno w sprawach indywidualnych, jak i grupowych.

Wśród zadań Rzecznika znajduje się między innymi dbałość o to, by szanowane były zasada wolności gospodarczej, dobre obyczaje oraz słuszne interesy przedsiębiorców. Rzecznik nie jest zatem powołany wyłącznie do tego, aby dyscyplinować organy administracji w ich relacjach z przedsiębiorcami, lecz także aby pogłębiać zaufanie przedsiębiorców do organów władzy publicznej. Pośrednio Rzecznik może wpływać również na relacje przedsiębiorców między sobą. Dotyczy to zwłaszcza sytuacji, gdy w grę wchodzi poszanowanie dobrych obyczajów i zasady uczciwej konkurencji. Rzecznik może też pomagać w organizowaniu mediacji pomiędzy przedsiębiorcami a organami publicznymi. Ponadto może występować o wydanie objaśnień prawnych oraz zwracać się do organów, organizacji i instytucji publicznych o podjęcie wszelkich działań mających skutkować poprawą ochrony praw przedsiębiorców i żądać od tychże zajęcia stanowiska. Zaliczyć do nich należy podjęcie inicjatywy ustawodawczej w kwestiach na przykład likwidacji obciążeń fiskalnych czy formalnych nakładanych na przedsiębiorców.

Organy publiczne zaś mają obowiązek współdziałania z Rzecznikiem i rozpatrywania spraw do nich skierowanych. Wydaje się, iż Rzecznik dysponuje skutecznymi instrumentami nacisku na organy administracji publicznej przez żądanie od nich podjęcia określonych kroków, a w wypadku ich nieuzasadnionego zaniechania — zwrócenie się do jednostki nadrzędnej o ich podjęcie. Z kolei stwierdzenie naruszenia praw przedsiębiorców przez organy administracji pozwala mu na złożenie wniosku do właściwych podmiotów o wszczęcie postępowania wyjaśniającego lub dyscyplinarnego. Elementem wspierającym przedsiębiorców jest

13 Ustawa z dnia 6 marca 2018 roku o Rzeczniku Małych i Średnich Przedsiębiorców; zob. też H. Wolska, [w:] A. Dobaczewska, A. Powałowski, H. Wolska, Nowe prawo przedsiębiorców, Warszawa 2018, s. 142-147. 
także ich prawo do wnioskowania o podjęcie czynności przez Rzecznika, który nie może pozostawić takiego wniosku bez jakiekolwiek ustosunkowania się do niego.

Novum stanowi też nałożenie na wszystkie organy uprawnione do przedkładania Radzie Ministrów projektów aktów normatywnych obowiązku dążenia do zapewnienie jednolitego stosowania prawa. Jednym z przyczynków do takiego stanu rzeczy są objaśnienia prawne, o które może wnioskować, z urzędu lub na wniosek zainteresowanych przedsiębiorców, właśnie Rzecznik ${ }^{14}$. Godzi się wspomnieć, że powstały ponadto cztery biura terenowe ${ }^{15}$ Rzecznika, co pozwala na łatwiejszy kontakt przedsiębiorców z reprezentantem ich interesów. Realizację zadań Rzecznika powinno też ułatwiać powołanie rady przedsiębiorców jako organu doradczego, w którego skład wchodzą przedstawiciele przedsiębiorców.

Nie do końca przekonuje natomiast wydzielenie do odrębnego aktu prawnego regulacji odnośnie do Rzecznika Małych i Średnich Przedsiębiorców. Podstawy prawne funkcjonowania tej instytucji mogłyby z równie dobrym powodzeniem znaleźć się w ustawie Prawo przedsiębiorców.

Niepewność prawa mają rozwiać objaśnienia prawne, o których wydanie może wystąpić Rzecznik. Jest to instrument podobny do interpretacji ogólnych oraz objaśnień prawa podatkowego. Ustawodawca przewidział również możliwość składania wniosków o interpretacje indywidualne w sprawach dotyczących obowiązku świadczenia przez przedsiębiorcę „daniny publicznej lub składek na ubezpieczenia społeczne lub zdrowotne". W zakresie podatków, tworzących przecież grupę danin publicznych, powielono więc uprawnienia nadane podatnikom (w tym przedsiębiorcom) przez ustawę Ordynacja podatkowa, a powtórzeniem art. 10 ustawy o swobodzie działalności gospodarczej są wnioski o wydanie interpretacji dotyczących składek na ubezpieczenie w ZUS ${ }^{16}$. Brakuje za to rozgraniczenia, czy i kiedy można skorzystać z tych uprawnień - alternatywnie czy równolegle do siebie - zwłaszcza że podlegają one alternatywnie przepisom k.p.a. albo ustawy Ordynacja podatkowa ${ }^{17}$. W ustawie Prawo przedsiębiorcy interpretacja przyjmuje postać decyzji, od której służy odwołanie. Ustawa ta przyjmuje, że taka decyzja nie jest wiążąca dla przedsiębiorcy (sic!), ale w wypadku zastosowania się do niej nie mogą być na przedsiębiorcę nakładane sankcje administracyjne, finansowe ani kary (przy czym można się jedynie domyślać, że chodzi o kary pieniężne). $\mathrm{W}$ doktrynie prawa podatkowego wiele napisano na temat charakteru dokumentu zawierającego interpretację podatkową oraz o jego formie, ostatecznie nie definiując jej jednak wprost ${ }^{18}$. Dlatego posłużenie się przez ustawodawcę

14 Od początku swego funkcjonowania do końca września 2019 roku złożył on 15 takich wniosków — https://rzecznikmsp.gov.pl/objasnienia-prawne/ (dostęp: 30.09.2019).

15 W Krakowie, Białymstoku, Poznaniu i Gdańsku.

16 P. Kostrzewa, Wiążace pisemne interpretacje ZUS. Komentarz praktyczny, LEX 2019.

17 L. Bielecki, [w:] Konstytucja biznesu. Komentarz, red. M. Wierzbowski, Warszawa 2019, LEX.

18 Co do charakteru prawnego interpretacji podatkowej zob. C. Kosikowski, [w:] J. Brolik et al., Ordynacja podatkowa. Komentarz, Warszawa 2013, s. 177.

Prawo 329, 2020

(C) for this edition by CNS 
ponownie formą decyzji do interpretacji indywidualnych jest najmniej trafnym wyborem z możliwych.

Podobnie pewności prawa służyć ma przepis art. 14 ustawy Prawo przedsiębiorców o nakazie nieodstępowania przez organy administracji od „utrwalonej praktyki rozstrzygania spraw" bez uzasadnionej przyczyny. Jest to oczywiste, bez konieczności akcentowania tego w osobnym przepisie. Po pierwsze, przy takim samym stanie prawnym i okolicznościach faktycznych organ administracji nie ma innej możliwości, co potwierdza także zasada budowania zaufania do organów administracji. Po wtóre, krytycznie należy ocenić fakt, że przedsiębiorcom nie przydzielono żadnego mechanizmu kontroli, kiedy można uznać, że praktyka jest „utrwalona” ani czy przyczyna odstępstwa jest (czy nie jest) „uzasadniona”. Brakuje też jakichkolwiek wskazówek co do tego w samej ustawie. Jest to więc deklaracja niewnosząca żadnej realnej korzyści dla przedsiębiorców.

Kolejnym etapem wspierania przedsiębiorców w prowadzeniu działalności jest nowelizacja licznej grupy przepisów (zwłaszcza podatkowych), zawarta w ustawie z 9 listopada 2018 roku ${ }^{19}$ (ustawy określanej inaczej „,pakietem MŚP”). W rzeczywistości pakiet ten nie wprowadził żadnych nowych jakościowo rozwiązań. Jego główną zaletą jest to, że w znacznej liczbie przypadków dokonano obniżenia, względnie podwyższenia, relewantnych limitów (na przykład osiąganych obrotów czy liczby osób zatrudnianych), od których ustawy uzależniały powstanie różnorakich obowiązków sprawozdawczych; skrócenia okresu, po jakim można rozliczyć tak zwane złe długi z tytułu VAT (z 120 dni na 90 dni) itp. Jednocześnie podwyższono pułap przychodów (z 1,2 do 2 milionów euro), do których podmiot uważa się na tak zwanego małego podatnika. Bez wątpienia pozwoli to dodatkowej grupie przedsiębiorców zaniechać dokonywania wybranych formalnych obowiązków z zakresu podatków. Zmniejszenie obciążeń formalnych powinno pośrednio pozwolić na obniżenie obowiązkowo ponoszonych kosztów działalności. Ustawodawca dla poszczególnych sprawozdań przyjął jednak różne limity kwotowe (dotyczące obrotów przedsiębiorcy) warunkujące zwolnienie z obowiązków sprawozdawczych. Gdyby kwota obrotów zwalniająca z obowiązków sprawozdawczych była za każdym razem jednakowa (na przykład 2 miliony euro), pozwoliłoby to mikroprzedsiębiorcom zredukować niepewność co do ich konkretnych obowiązków i byłoby to rozwiązanie przyjazne całej tej grupie przedsiębiorców.

Ostatnią składową zmian prawnych i ułatwień wspierających przedsiębiorców jest pakiet zmian nazwany Przyjazne Prawo, czyli ustawa z 31 lipca 2019 roku $^{20}$, mająca za zadanie daleko idącą deregulację działalności gospodarczej. Obowiązuje ona co do zasady od 1 stycznia 2020 roku. Elementem zasługującym na szczególne uwzględnienie przy omawianiu wzajemnych relacji przedsiębiorców z organami administracji jest rozwiązanie prawne zwane potocznie „pra-

19 Ustawa z dnia 9 listopada 2018 roku o zmianie niektórych ustaw w celu wprowadzenia uproszczeń dla przedsiębiorców w prawie podatkowym i gospodarczym (Dz.U. z 2018 r. poz. 2244).

20 Ustawa z dnia 31 lipca 2019 roku o zmianie niektórych ustaw w celu ograniczenia obciążeń regulacyjnych (Dz.U. z 2019 r. poz. 1495). 
wem do błędu”. Oznacza ono, w pewnym uproszeniu, że przedsiębiorcy będący osobami fizycznymi (wpisani do CEIDG) mogą powołać się przez pierwszy rok prowadzenia działalności na swoją niewiedzę czy błędne rozumienie przepisów prawa o mniejszym znaczeniu, bez ryzyka ponoszenia z tego powodu konsekwencji. Mogą zostać zwolnieni z mandatu karnego czy kary pieniężnej. Takie prawo nie dotyczy jednak ani rażącego naruszenia prawa, ani sytuacji gdy naruszenie prawa jest nieusuwalne (przy czym to do organu należy wykazanie takiego charakteru naruszenia). Nie jest też jasno sprecyzowane, czy na prawo do błędu można powołać się także później, o ile tylko naruszenie prawa miało miejsce w pierwszym roku działalności, ani czy można się na to powołać, jeśli błąd wystąpił na początku działalności i trwa nadal. Istnieje zatem spore prawdopodobieństwo, że przepis ten będzie stosunkowo rzadko stosowany.

Na wzajemne relacje organów władzy publicznej państwa i przedsiębiorców wpływ mają przepisy umożliwiające zawieranie ugody ze stroną postępowania. O ile w k.p.a. po nowelizacji z 2017 roku przewidziano możliwość zawarcia ugody pomiędzy stronami w postępowaniu administracyjnym, to wspomniana ustawa przewiduje możliwość zawarcia ugody przez przedsiębiorcę z organami administracyjnymi w sprawie z odwołań od decyzji Prezesa UOKiK lub organów regulacyjnych (energetyki, komunikacji elektronicznej, kolei itp.). Zawarcie ugody nie jest już obarczone ryzykiem zarzutu naruszenia dyscypliny finansów publicznych przez organ administracji. Należy mieć zatem nadzieję, że rozwiązanie to będzie wykorzystywane. Pozwoli bowiem przedsiębiorcom przyspieszyć ostateczne rozstrzygnięcie, zaoszczędzić na kosztach czy zyskać pewność prawa.

Reasumując, należy wskazać, że ocena zmian wprowadzonych w latach 2015-2019, a dotyczących relacji wzajemnych organów administracji publicznej z przedsiębiorcami nie wypada jednoznacznie. Nowelizacje nie wprowadzają w istocie zbyt wielu nowych rozwiązań i zasad, powielając raczej unormowania z innych aktów prawnych albo stanowiąc jedynie potwierdzenie zasad obowiązujących na innych podstawach. Są jednak wśród nich także nowe zapisy, takie jak mediacje przedsiębiorców z organami administracji czy możliwość zawierania ugody z (ustawowo wskazanymi) organami administracji. Niewątpliwym ułatwieniem dla przedsiębiorców jest okoliczność, że zasady kreujące postawę organów administracji wobec przedsiębiorców zostały jasno sprecyzowane i zawarte w najważniejszym dla nich akcie prawnym.

\section{Bibliografia}

Bielecki L., [w:] Konstytucja biznesu. Komentarz, red. M. Wierzbowski, Warszawa 2019. Bonarska-Lenarczyk K., Kowalska-Czarnota B., Konstytucja biznesu. Komentarz, 2019 [e-book]. CEIDG. Rzecznik Matych i Średnich Przedsiębiorców. Przedsiębiorcy zagraniczni w obrocie gospodarczym. Komentarz, red. G. Kozieł, Warszawa 2019. 
Grzegorzewska-Mischka E., Wyrzykowski W., Bariery rozwoju przedsiębiorczości w Polsce i krajach UE - analiza retrospektywna i porównawcza, [w:] Przedsiębiorczość w dobie wyzwań rozwojowych, red. Ł. Sułkowski, A. Marjański, „Przedsiębiorczość i Zarządzanie” 18, 2017, nr 12, cz. 1.

Kosikowski C., [w:] J. Brolik, R. Dowgier, L. Etel, C. Kosikowski, P. Pietrasz, M. Popławski, S. Presnarowicz, W. Stachurski, Ordynacja podatkowa. Komentarz, Warszawa 2013.

Kostrzewa P., Wiążace pisemne interpretacje ZUS. Komentarz praktyczny, LEX 2019.

Prawo przedsiębiorców. Komentarz, red. A. Pietrzak, Warszawa 2019.

Samborski A., Bariery fiskalne rozwoju przedsiębiorczości w Polsce, „Problemy Zarządzania” 2017, nr 1 (65).

Sikorska-Lewandowska A., Zasady prowadzenia działalności gospodarczej w świetle ustawy Prawo przedsiębiorców, „Przegląd Prawa Handlowego” 2019, nr 1.

Strzyczkowski K., Prawo gospodarcze publiczne, Warszawa 2011.

Wolska H., [w:] A. Dobaczewska, A. Powałowski, H. Wolska, Nowe prawo przedsiębiorców, Warszawa 2018.

\section{Legal principles on the mutual relationships of entrepreneurs and public authorities}

\section{Summary}

This article is an evaluation whether and to what extent the legislative changes within the period 2015-2019 have brought actual changes for entities conducting business activity, especially regarding their relations with public administration; including the attitude of authorities towards entrepreneurs. No less important are the main principles the legislator should adopt while issuing legal acts constituting requirements for establishing and conducting business activity. The article concentrates on the potential differences between a catalogue of principles in the Constitution of the Republic of Poland and the Act on Administrative Procedure and the principles on business activity and on passing of public economic law, the latter included in the Act on Entrepreneurs Law.

Keywords: support of entrepreneurship, small entrepreneurs, micro entrepreneurs, Business Act. 